\title{
Pretilost - gojaznost
}

\author{
Dragana Ivanović \\ ZU Apoteka Požarevac, Golubac, UFTS Sveti Sava
}

$\mathbf{P}$ aradoks je da su glad sa jedne strane i gojaznost sa druge strane istinski svetski problemi. Prema podacima Svetske zdravstvene organizacije, više od milijardu odraslih osoba na našoj planeti ima prekomernu telesnu masu. Veliki problem predstavlja činjenica da je sve više gojazne dece. Gojaznost je često uzrok drugih bolesti: hipertenzije, dijabetesa tipa 2, moždanog udara, malignih bolesti, osteoartritisa, gihta i dr. S obzirom na to koliki uticaj ima na zdravlje, gojaznosti treba da posvete mnogo veću pažnju ne samo zdravstveni radnici nego i društvo u celini.

Do gojaznosti dovode loše životne navike, pre svega nepravilna ishrana i odsustvo fizičke aktivnosti. Prema tome, kada bi smo se pravilno hranili i bili dovoljno fizički aktivni, ne bi bilo problema sa viškom kilograma. Gojaznost je hronična bolest, ne može da se reši preko noći, pa je zato neophodna edukacija pacijenata o pravilnoj ishrani i zdravim stilovima života. Pravilna ishrana je obavezan deo prevencije bolesti.

\section{ISTINA - hormoni diktiraju koliko žudimo za hranom.}

Svetska zdravstvena organizacija je objavila da je gojaznost bolest pandemijskog značaja koja ugrožava razvijeni svet. Gojaznost je poremećaj energetskog bilansa u kome je hronični unos kalorija veći od njihove potrošnje. Energetski bilans zavisi od unosa hrane, deponovanja energije u masnom tkivu i potrošnje energije.

Gojaznost je multifaktorski poremećaj. Najznačajniji faktori su: genetski, metabolički, nezdrav način života, ishrana neprimerena potrebama organizma, brza hrana, velike porcije, emocionalno prejedanje, sociokulturološki, psihološki i neurološki faktori.

Simtomi gojaznosti: gubitak daha pri manjem naporu, umor, depresija, teškoće pri spavanju, bol u leđima, kukovima, kolenima, gubitak libida, menstrualni poremećaji, menoreja, oligomenoreja, neplodnost, izraženo znojenje. Indeks uhranjenosti određuje se BMI-Body Mass Indexom( indeksom telesne mase) :

Gde su:

$\boldsymbol{m}$ - masa osobe u kilogramima

$\boldsymbol{h}$ - visina osobe u metrima

Tretman gojaznosti ima za cilj:

- spečavanje daljeg dobijanja u težini

- smanjenje telesne težine

- održavanje telesne težine u dužem periodu.

\section{ZANIMLjIVOST-mišićave osobe imaju visok BMI bez dodatnog rizika po zdravlje.}

Naslage na stomaku povećavaju rizik od oboljenja srca, moždanog udara, artritisa. Pojedini hormoni utiču na raspored masnog tkiva u telu. Na primer: u menopauzi zbog smanjenog nivoa estrogena dolazi do skladištenja masnoća na stomaku i naglog dobijanja viška kilograma. Procena faktora rizika po zdralje: povišen nivo triglecerida, holesterola, nivo glukoze u krvi, povišen krvni pritisak i abdominalna gojaznost.

Pretilnost je hronična bolest, nastaje prekomernim nakupljanjem masnog tkiva u organizmu, a time i povećanjem telesne težine. Indeks telesne mase preko $30 \mathrm{~kg} / \mathrm{m}^{2}$ ukazuje na pretilnost, dok osobe sa prekomernom telesnom težinom imaju indeks telesne mase od 25 do $29.9 \mathrm{~kg} / \mathrm{m}^{2}$. Metabolički sindrom predstavlja skup kardiovaskularnih faktora rizika u osoba sa insulinskom rezistencijom ili kod gojaznih. Uveden je u kliničku praksu zbog neophodnosti definicije faktora rizika i njihovog suzbijanja radi sprečavanja daljeg širenja epidemija XXI-og veka: gojaznosti, dijabetesa, kardiovaskularnih oboljenja ukIjučujući i hipertenziju. Smatra se da su glavni etiološki faktori insulinska rezistencija i abdominalna gojaznost. Patogeneza je kompleksna. Ukratko, metabolički sindrom je grupa karakteristika, to nije bolest, naziva se još sindrom insulinske rezistencije ili sindrom $\mathrm{H}$.

Dijagnoza metaboličkog sindroma je abdominalna gojaznost i 2 od ostala 4 faktora. Premetabolički sindrom je prisustvo 1 do 2 faktora rizika i bitan je za početak korigovanja telesne težine i suzbijanje razvijanja metaboličkog sindroma. Primarna terapijska mera je: umerena restrikcija kalorija, umeren porast fizičke aktivnosti i promena navika ishrane. Sekundarna terapijska mera je primena lekova.

Potreba za hranom se javlja kad se oseti glad. Glad se definiše kao želja za hranom. Simtomi gladi: kontrakcije želuca - grčevi gladi, poznati kao krčanje creva; napetost, nemir.

Apetit je želja za određenom vrstom hrane. Sitost je osećaj suprotan osećaju gladi, ne postoji potreba za unošenjem hrane. Takav osećaj se javlja posle obroka i manifestuje se kao zadovoljstvo, fizička i psihička obamrlost. Centri za uzimanje hrane nalaze se u lateralnom delu hipotalamusa. Želja za unošenjem hrane nastaje kada je hipotalamus nadražen. Hipotalamus kontroliše hranu koja se unosi i postiže ravnotežu između unošenja i količine hranljivih materija koja se razgradi pri metaboličkim procesima. Na unošenje hrane utiču: 
- viši delovi nervnog sistema

- pojedini produkti metabolizma i veliki broj digestivnih enzima

Regulaciju unošenja hrane delimo na kratkoročnu i dugoročnu. Dugoročna regulacija odvija se tokom nedelja i meseci i time se obezbeđuje fiziološka rezerva hranljivih materija. Ova regulacija omogućena je mehanizmom negativne povratne sprege. Kratkoročna regulacija je na dnevnom nivou i sastoji se u navici da se hrana uzima u određeno vreme, npr. broj obroka. Omogućena je refleksima digestivnog trakta - rastezanje želuca usled prisustva hrane, refleksi pri žvakanju, gutanju, lučenju pljuvačke.

Cilj ovih mehanizama je da se održi ravnoteža između unosa hrane i energetskih potrebe organizma. Kada dođe do poremećaja ove ravnoteže javlja se gojaznost ili pothranjenost.

Cirkadijalni ritam su ciklične promene u našem fizičkom, psihičkom i mentalnom funkcionisanju tokom 24 sata. Promene su u stvari odgovor našeg organizma na promenu dnevne svetlosti, u stvari, na gubitak i pojavljivanje dnevne svetlosti. Cirkadijalni ritam se javlja i kod životinja i kod biljaka.

Naš oganizam ima svoj master clock - glavni sat sastavljen od mreže preko 20000 moždanih ćelija koje kontrolišu cirkadijalni ritam, što direktno utiče na pospanost budnost, lučenje hormona, na lučenje melatonina na telesnu temperaturu i dr. Kada je napolju mrak a osoba je pod uticajem veštačke svetlosti smanjeno je lučenje melatonina što dovodi do poremećaja spavanja i to je put do nesanice.

Osobe na dijeti često ne mogu da izdrže glad. Upravo zbog toga je neophodno količinu masnog tkiva dovesti u normalu, da bi leptin i grelin odradili svoj deo posla. Iz tih razloga dijete moraju biti planski sprovedene.

\section{Principi pravilne ishrane}

\section{Krilatica: HRANA KAO LEK, A LEK KAO HRANA!}

\section{ZANIMLjIVOSTI jo - jo efekat je ostao u našim genima od predaka. Zahvaljujući njemu naši preci su živeli od ulova do ulova. $U$ vreme gladovanja njihov organizam je maksimalno štedeo rezerve. Danas je to uzrok mnogih neuspešnih dijeta.}

Za dobro zdravlje najznačajniji su: životna sredina, pravilna ishrana i zdrave životne navike.

Hipokrat, najveći lekar antičkog sveta, još pre dva i po milenijuma je ustanovio da izbor hrane utiče na zdravlje ljudi. Postavio je prve temelje zdravstvene zaštite. Pravilna ishrana je postala jedna od najvažnijih ideala stare Grčke.

Naučne discipline koje se danas bave izučavanjem ishrane su bromatologija i dijetetika. Pod racionalnom ishranom podrazumevamo način na koji možemo da zadovo- ljimo energetske potrebe organizma. Postavljena su četiri principa:

1. Energetske potrebe zadovoljavaju se:

- 55-60 \% iz ugljenih hidrata od čega: 45-50 \% iz složenih, a $10 \%$ iz prostih šećera

- 25-30 \% iz masti, koje su rezervni izvor energije u stanju gladovanja kada je neophodna energija za bazalni metabolizam; deponuju se u masnom tkivu.

- 12-15 \% iz proteina kojima su najvažnije uloge gradivna i imunološka

2. Biomolekuli bez kojih nema normalnog funkcionisanja organizma: vitamini, minerali, esencijalne aminokiseline i esencijalne masne kiseline.

3. Ovaj princip govori o odnosu unosa proteina i masti biljnog i životinjskog porekla

4. Hrana mora biloški vredna i zdravstveno ispravna.

Ubrzani industrijski razvoj doveo je do pada u kvalitetu ishrane. Zaboravlja se da nam hrana pruža mnogo toga - podiže raspoloženje, izvlači iz depresije; ali može da utiče na agresiju. Pravilna ishrana podrazumeva pravilan izbor namirnica, pravilnu količinu, pravilnu pripremu obroka. Važno je izbegavanje prejedanja - unošenje suvišnih kalorija.

Mediteranska ishrana je bitna jer je unjoj zastupnjeno obilje voća, povrća, žitarica koje su bogate dijetetskim vlaknima i antioksidansima, plave ribe dubokih mora skuša, tuna, losos, masline, orašasti plodovi posebno orah i maslinovo ulje. Unos dijetetskih materija je preko potreban, jer današnja hrana ima 5-8 grama a treba dnevno uneti 30-35 grama. Glavni izvor dijetetskih vlakana su voće, povrće, integralne žitarice.

Osnovni postulati pravilne ishrane:

- Adekvatna - sadrži dovoljnu količinu i optimalan odnos nutrijenata, osigurava osećaj sitosti

- Umerena - kontrola količine porcije

- Uravnotežena - prisustvo odgovarajućih grupa namirnica, dobar odnos čvrstih i tečnih namirnica

- raznovrsna - što više boja u tanjiru

- preporuke za procetntualni unos energije po obroku: doručak 20-25 \%, užina 5\%, ručak 35-40\%, užina 5-10\%, večera $25-30 \%$.

Šta ne treba jesti i piti?

- prženo i pohovano na ulju

- suhomesnate proizvode, iznutrice, paštete, umake

- šećerne koncetrate: torte, kolače, mlečne čokolade

- gazirane napitke

Izbeći sedanterni način života.

Nutrijenti su sastojci hrane koji obezbeđuju fiziološke funkcije organizma. To su: makronutrijenti (proteini, masti, ugljeni hidrati), vitamini, minerali i voda.

Proteini su prvenstveno gradivni nutrijenti, sastoje se od 9 esencijalnih i 11 amino kiselina koje može da sintetiše organizam. Oorganizma ali i energetske su materije u slučaju kada nema dovoljno ugljenih hidrata i masti.

\section{$1 \mathrm{~g}$ proteina $=4 \mathrm{kcal}$}

Ugljeni hidrati su nosioci energetskih potreba organizma, ali su bitni i kao izvor dijetetskih vlakana. Podela ugljenih hidrata: 
- $\quad$ prosti - to su monosaharidi: glukoza, fruktoza; i disaharidi

- složeni - polisaharidi: skrob, celuloza

$1 \mathrm{~g}$ ugljenih hidrata $=4 \mathrm{kcal}$

Masti su izvor energije ali i nosioci esencijalnih masnih kiselina i liposolubilnih vitamina, pored toga masti su i gradivne materije. Delimo ih na zasićene i nezasićene masti.

\section{$1 \mathrm{~g}$ masti $=9 \mathrm{kcal}$}

Trans-masne kiseline nastaju kada se polinezasićena ulja hidrogenizuju da bi postala čvrsta i da bi im se produžio rok trajanja.

Zdravstvena piramida ishrane deli sve životne namirnice u 6 kategorija. $U$ isto vreme ukazuje slikovito na najbolje izvore tih hranljivih i zaštitnih materija. Poštujući te preporuke osigurava se ravnomeran unos namirnica koje imaju hranljivu i zaštitnu vrednost.

Tabela 1. Prosečne vrednosti dobijene sagorevanjem proteina, masti, ugljenih hidrata i alkohola.

\begin{tabular}{|l|c|c|}
\hline Materija & kcal/g & kJ/g \\
\hline Proteini & 4 & 17 \\
\hline Masti & 9 & 37 \\
\hline Ugljeni hidrati & 4 & 17 \\
\hline Alkohol & 7 & 29 \\
\hline
\end{tabular}

\section{Nula kalorija - nula krivice}

Dijeta je terapija koju propisuje lekar kao osnovno ili pomoćno sredstvo kod lečenja nekih bolesti (celijakije, hipertenzije, poremećaja masnoće i šećera u krvi i drugo). Pod dijetama u svakodnevnom životu podrazumeva se restrikcija hrane u cilju regulacije telesne mase. Sam naziv - restrikcija hrane ukazuje na mehanizam; isključivo funcionišu tako što obezbeđuju manje kalorija nego što je potrošnja. Gubitak težine zavisi od deficita kalorija.

Medicinske dijete su individualne. Kada se utvrdi zdravstveno stanje osobe, prisustvo ili odsustvo nekih bolesti, urade laboratorijske analize, izračuna energetska potreba osobe, određuje se 30\% deficita energije ili 500-1000 kcal manje u odnosu na ono što je utvrđeno kao energetska potreba pojedinca. U praksi to su dijete 1200 1500 kcal za žene i 1500-1800 kcal za muškarce. Izbor namirnica zavisi od zdravstvenog stanja pacijenta, navika, materijalnog stanja, jer se zasnivana na izmenama namirnica iz 7 osnovnih grupa: žitarice i zamena; mleko i mlečni proizvodi; meso, jaja, riba i mahunarke; povrće, voće, vidljive masti i šećer. Da bi restrikcija kalorija bila kontrolisana, postiže se kontrolom porcije, odnosno merenjem. Gubitak u težini je za 3 meseca 10-15 kg. Kako su prisutne sve neophodne hranljive materije mogu se koristiti duži vremenski period, koliko je potrebno. Formule dijete - prašak ili napitak u kome su upakovani najvažniji hranljivi sastojci u svega 600-800 kcal. Gubici u težini su ovde najveći-preko $20 \%$ početne težine za 3 meseca. Ovakav proizvod mora da ispuni 2 uslova:
- prisustvo belančevina, vitamina i minerala

- nepromenljivost sadržaja proizvoda duže od 3 meseca Dijetetski suplementi koji se nalaze u slobodnoj prodaji na tržištu deluju tako što:

- Izazivaju osećaj sitosti jer bubre i zadržavaju vodu u lumenu creva, povećavaju zapreminu crevnog sadržaja i time ubrzava peristaltiku, deluju laksativno (metilceluloza, psilijum).

- Povećavaju izlučivanje tečnosti iz organizma (maslačak, kofein)

- Blokiraju apsorpciju masti (hitozan)

- Utiču na metabolizam masti (L-karnitin, zeleni čaj)

Najčešće komponente dijetetskih suplemenata:

PEKTIN - je složeni ugljeni hidrat koji se ne resorbuje iz digestivnog trakta, te spada u dijetna vlakna. Najviše ga ima u ljuskama voća. Rastvorljiv je u vodi. Delovanje dijetnih vlakana - vezuju holesterol, minerale, toksične elemente. Potreba odraslih osoba je 20 grama dnevno, dok veći unos može smanjiti resorpciju kalcijuma, gvožđa, karotenoida, tetraciklina, digiksina, klindamicina. Trudnice i dojilje poželjno je da izbegavaju veću količinu zbog intestinsInih tegoba.

HITOZAN - dobijen iz hitinskog omotača rakova i školjki. Ovaj polisaharid nalazi se i u gljivama. Spada u dijetna vlakna nerasvorna u vodi. Utiče na laksaciju, motalitet creva, smanjuje resorpciju masti i ugljenih hidrata. Iz tih razloga ima dobar učinak na nivo holesterola u krvi. Zbog mogućih intestinalnih tegoba ne treba da koriste deca, trudnice i dojilje. Uzima se 2 sata pre jela jer može da veže neke minerale, cink, liposolubilne vitamine $A$, D, E, K, karotenoide, flavonoide, lipofilne lekove.

L-KARNITIN (levokarnitin) je hidrosolubilni kvaternalni amin. Oganizam može da ga sintetiše od aminokiseline lizin i metionin. Nalazi se namirnicama biljnog i životinjskog porekla: goveđem i svinjskom mesu, ribi, mleku, mlečnim proizvodima, avokadu i nekin fermetisanim sojinim proizvodima. Uloga ove supstance u organizmu je da deluje na transport masnih kiselina kroz mitohondrijalnu membranu, u metabolizmu masti i njenom iskorišćavanju kao izvora energije što je bitno za srčane i skeletne mišiće. Otuda njegovo kardioprotektivno delovanje: snižava nivo triglicerida i povećava nivo HDL holesterola. Ne davati deci, trudnicama dojiljama i osobama koje boluju od epilepsije.

\section{FORMULA MRŠAVLjENjA = DIJETA + DISCIPLINA + DOSLEDNOST}

BROMELIN - proteolitički enzim ananasa. Sadrže ga pored ananasa i papaja, kivi i smokva. Pomaže proteolitičkim enzimima čoveka u digestiji. Ne davati deci, trudnicama, dojiljama i osobama sa antikoagulantnim i antitrombotskim lekovima.

Farmakološka terapija se primenjuje kod pacijenata koji ne mogu da smanje svoju telesnu težinu primenom nefarmakoloških mera tokom 3-6 meseci. Registrovani lek je: ORLISTAT - mehanizam dejstva zasniva se na inhibiciji lipaza gastrointestinalnog trakta, masti unete hranom zbog toga se ne razgrađuju do masnih kiselina i i triglicerida, čime je resorpcija masti smanjena za oko $30 \%$. Indikacija za upotrebu ovog leka je BMI > 30 ili BMI > 27 
i prisustvo nekih od faktora rizika: hipertenzija, dislipidemija, dijabetes tipa 2, opstruktivna SLEEP apnea. Uobičajene gastrointestinalne smetnje kod upotrebe ovog leka su: masna urgentna stolica i hitni nagon za defekacijom. Kontraindikacije: holestaza, laktacija i trudnoća. Upotreba: uz glavni obrok, najkasnije 1 sat posle jela.

Savetodavna uloga zdravstvenih radnika je da ukažu pacijentu na neophodnost ostvarivanja balansa između energije koja se unese i one koju troše na dnevnom nivou. Idealna težina se ostvaruje dijetama u kojima postoji kalorijski deficit od 500 do 1000 kcal.

Nefarmakološki tretman povećane telesne težine obuhvata:

- restrikcija ishrane

- svakodnevna fizička aktivnost od 30 minuta

- bihejvioralna terapija - pronalazi način za prevazilaženje individualne barijere za gubitak težine. Osoba mora da postane svesna da ostvarujući idealnu težinu utiče povoljno na svoje zdravstveno stanje. Zdravi životni stilovi ne mogu se postići brzo.

\section{BITNO: Izbalansirana, a ne restriktivna ishrana.}

Kod izbora namirnica vodi se računa o raznovrsnosti hrane, ukusu, navikama, materijalnoj mogućnost osobe kojoj se ishrana određuje.

Osnovno pravilo: česti manji obroci ravnomerno raspoređeni, zastupljene esencijalne hranljive materije u količini hrane koja ne opterećuje metabolizam velikom energijom. Važno je da se ni jedna namirnica ne isključi potpuo iz ishrane.

Važno je sprečiti oksidativni stres organizma, koji podstiče zapaljenske procese, remeti imunitet, smanjuje fizičku izdržljivost. Antioksidansi iz voća i povrća kao i odgovarajući dijetetski suplementi dobar su izbor u borbi protiv oksidativnog stresa i slobodnih radikala.To je sve u cilju unapređenja zdravlja, a ne samo gubitka kilograma.

Debljina je uglavnom bolest poremećaja jedenja, pa je neophodno shvatiti uzrok prekomernog unosa hrane. Zbog toga je neophodno promeniti ponašanje u vezi sa ishranom i pronaći svoj program vežbi.

Saveti:

- dovoljno sna, sprečiće potrebu za prostim šećerima i belim ugljenim hidratima

- uravnotežena ishrana: doručak, ručak, večera i dve užine

- kontrolisati veličinu porcije

- belančevine daju osećaj sitosti

- užine održavaju gladi pod kontrolom i onemogućavaju oscilaciju šećera u krvi

- ponešto i udovoljiti sebi

Ako se kilogrami gube suviše brzo, može imati negativne posledice po zdravlje (nervoza,usporenost, iscrpljenost). Brzo gubljenje kilograma je u suštini gubitak tečnosti i mišićne mase, jer telo čuva masno tkivo. Telo prvo koristi energiju iz ugljenih hidrata, tek kada se oni iskoriste prelazi se na mast.

Kalorijski deficit - unos se smanjuje za 200-500 kcal od potrebe organizma, jer sa konstantnim unosom mnogo manje hrane organizam privikava na to i dolazi do efekta-usporenog metabolizma. Kako bi se to izbeglo treba jedanput u 2 nedelje uneti optimalne dnevne potrebe organizma.

Dnevne energetske potrebe kod pretežno sedenternih osoba je $2200-2500$ kcal muškarca i $1800-2100$ kcal žene. Prosečni bazalni metabolizam je 1000-2400 kcal. Osobe sa većom količinom mišića imaju i veći bazalni mrtabolizam. Žene imaju veći procenat masnog tkiva i niži procenat mišićne mase od muškarca. Svaka fizička potreba podrazumeva i potrošnju energije.

Korekcija dnevnih energetskih potreba vrši se u odnosu na spoljašnju temperaturu. Svako povećanje temperature iznad 10 stepeni prosečne godišnje temperature, zahteva smanjenje energetskog unosa za 5\%. Smanjenjem temperature za 10 stepeni zahteva povećanje energetskog unosa za $5 \%$.

\section{ZANIMLjIVOST: Da bi se telesna težina povećala za $1 \mathrm{~kg}$ potrebno je telu $7000 \mathrm{kcal}$.}

$1 \mathrm{kcal}=4.184 \mathrm{~J}$

Usavršene su 2 metode barijatrik hirurgije: restriktivni zahvati na želucu čime se isključuje $90 \%$ donjeg želudačnog džepa što ograničava veći unosa hrane zbog manjeg želudačnog prostora, pa se oseća punoća nakon manjeg obroka; i malabsorptivna operacija (bypass-premošćavanje želuca) na digestivnom traktu kojom se utiče na varenje i resorpciju hrane.

Kada mršavljenje ne uspeva?

- osećate se lišeni nečega - eliminisanje cele jedne grupe namirnica stvara se izrazita neravnoteža u ishrani što može imati negativne posledice

- mršavljenje prestaje posle samo par kilograma - suština je da uz promenu režima ishrane obavezno ide i fizička aktivnost. Kada nema fizičke aktivnosti ne mogu se utrošiti kalorije, a telo se brzo navikne na promenu ishrane

- pravilna ishrana je ono čemu se teži

\section{Fizička aktivnost}

Prilikom vežbanja dolazi do intezivnog energetskog metabolizma koji dovodi do stvaranja toplotne energije i zagrevanja krvi i celog organizma. Fizička aktivnost ima brojne fiziološke i psihološke pozitivne efekte po zdravlje. Ne postoji deo našeg organizma na koji fizička aktivnost pozitivno ne utiče. Bitno je vežbati redovno, koliko osobi odgovara. Za fizičku aktivnost postoji indikacija i kontraindikacija. Postoji i doziranje: premala doza nema efekta, a predoziranje može biti štetno. Fizička aktivnost ima svoje oblike: hodanje, trčanje, plivanje, sportovi sa loptom... Učestalost: $5 \mathrm{~h}$ nedeljno umerene fizičke aktivnosti ili $3 \mathrm{~h}$ nedeljno intezivne. Trajanje: 30 minuta ili 3 sesije od 10 minuta, najmanje 20 minuta. Kako bi fizička aktivnost bila zadovoljstvo a ne obaveza a njeni efekti najbolji:

- izabrati deo dana koji najviše odgovara

- najmanje 2 sata nakon obroka ne ići na trening

- unositi tečnost da ne dođe do dehidratacije

- adekvatna odeća 
- vežbati uz muziku

- trening treba da se sastoji iz 3 dela:

o da se mišići zagreju

o maksimalno vežbanje

o mišiće opustiti, istegnutui pospešiti eliminaciju štetnih materija nastalih u toku vežbanja

\section{REDOVNOST - osnova uspeha kod skidanja kilograma.}

\section{Zdravi stilovi života}

Zdrave životne navike ne podrazumevaju robovanje. Umerenost isključuje grižu savesti. Za odricanje od loših navika i uvođenje pozitivnih, potrebno je vreme, strpljenje i dobra volja. Rezultati nisu trenutni, što deluje obeshrabrujuće ali obezbeđuju zdravlje i dugovečnost. Loše navike se ukratko menjaju primenom formule 505 i 30 minuta fizičke aktivnosti dnevno.

5 - pet obroka dnevno: doručak, ručak, večera, dve užine - izbalansirana ishrana bez prostih šećera, do 0.5 kafene kašičice morske soli dnevno, izbegavanje masne hrane, belog brašna i proizvoda od njega, izbegavanje gaziranih napitaka i alkoholnog pića osim 1 do 2 čaše crnog vina. $\mathrm{O}$ - nula: cigarete potpuno izbaciti iz upotrebe 5 - šetnja 5 km dnevno: šetnja takva da se oseti malo oštrije disanje i malo ubrzaniji srčani rad, unositi 2-2.5 litra tečnosti dnevno.

\section{SAVET JE KAO RICINUSOVO ULjE - LAKO GA JE DATI, A TEŠKO PROGUTATI.}

Živimo u vremenu u kome se sve manje pažnje posvećuje zdravom načinu života, nepravilno i uglavnom se nezdravo hranimo, previše se sedi, bez volje i vremena za rekreacijom i fizičkom aktivnošću. Nije dovoljno nekome reći kako da vežba, već mu te vežbe i pokazati, sa njim vežbati svakodnevno kako bi naučio, istrajao kada posustane i uspe u pobedi nad svojim sedentarnim načinom života koji je dobrim delom i doveo do povećane telesne težine.

\section{Literatura}

1. Kažić T. 2013. Gotovi lekovi - priručnik za farmakoterapiju (XIV izdanje). Beograd: Integra

2. Harison - principi interne medicine. 1997. (Urednici: Ivančević et all.). Split: Placebo

3. Boivin, A., Brochu, G., Marceau, S., Marceau, P., Hould, F.S., Tchernof, A. (2007)

4. Regional differences in adipose tissue metabolism in obese men. Metab Clin Exp, 56:533- 540.

5. Waki, H., Tontonoz, P. (2007) Endocrine functions of adipose. Tissue Annu. Rev. Pathol. Mech. Dis, 2, str. 31-56.

6. Mr.ph.spec. Ivanović LJ. Et all. (2015) Registar lekova 2015. BBSOFT.Beograd

7. Prof.dr Vasiljević N. Et.all.(2012) Praktikum iz higijene i medicinske ekologije za student medicine, Medicinski fakultet Univerziteta u Beogradu,str. 167-206.

8. http://www.planeta.rs/49/01medicina.htm 